\title{
6
}

\section{Asylum Procedures in Greece: The Case of Unaccompanied Asylum Seeking Minors}

\author{
Chrisa Giannopoulou and Nick Gill
}

\section{Introduction}

According to Human Rights Watch (2016), the violations of children's rights in Greece during 2015 and 2016 included, among others, arbitrary detention. Under international law, binding European directives, and national law, detention of unaccompanied asylum seeking children should be used 'only as a measure of last resort, in exceptional circumstances, and for the shortest appropriate period' (ibid.: 1). Human Rights Watch found that children often faced degrading conditions in police station cells and in Coast Guard facilities, and unsanitary conditions in pre-removal detention centres. In some cases, children said they were made to live and sleep in overcrowded, filthy, bug- and vermin-infested cells, sometimes without mattresses, and were deprived of appropriate sanitation, hygiene, and privacy. The national response capacity is very limited as there are only a small

At the time of the writing, the first author was working as a Legal Advisor for the NGO the Hellenic League for Human Rights in Skaramagas Refugee Camp, Attica Region, Athens. The fieldwork reported in this chapter was conducted solely by Chrisa Giannopoulou (hereafter 'Chrisa' in the text). Currently, she is a Post Doctoral Reserarcher at the Department of Geography, University of Aegean, Lesvos, Greece.

C. Giannopoulou $(\triangle)$

University of Macedonia, Athens, Greece

N. Gill

University of Exeter, Exeter, UK

e-mail:n.m.gill@exeter.ac.uk 
number of available places in shelters. In many cases unaccompanied minors are therefore put in protective custody (i.e. detention) until a place in a shelter is available.

The same report found that children detained in police custody are not provided with critical care and services. Under international standards, unaccompanied asylum seeking children should be able to receive medical treatment, psychological counselling, and legal aid, and be interviewed in a language they understand in order to identify and address any specific needs, including those deriving from gender-based violence or trafficking. In Greece, such children are often unable to receive counselling, information about the reasons for and duration of their detention, and legal aid. Although the provision of interpreters at asylum interviews with children is by no means a guarantee of effective communication (Keselman et al. 2008) the lack of interpreters is a significant practical barrier to providing care and information (for a discussion of the role and importance of interpreters, see Rycroft 2005; Gibb and Good 2014). Human Rights Watch interviewed 35 children who were in police custody in Greece in mid 2016 and none of them said they had been given an opportunity to speak to the police with the help of an interpreter.

Furthermore, all unaccompanied asylum seeking children should have a legal guardian appointed to defend their best interests and help safeguard against risks like trafficking. None of the children interviewed by Human Rights Watch while in police custody had met their legal guardian, nor were they even aware they had one. Unaccompanied children in detention have a right to recreation and to education as well, but Human Rights Watch (2016: 3) found 'no evidence that the unaccompanied children in police stations had access to educational opportunities or recreational activities'.

This raises the question of how these human rights failings have been allowed to come about. Although a lack of leadership and resources have certainly had an impact (indeed, the lack of resources for the protection of refugees in Greece has been a challenge for decades, see Black 1994), in this chapter we argue that these factors are only part of the explanation. It is entirely possible for formal legal rules to exist, but for 'informal social control' (Woodman 1998: 45) to impede and inhibit the operation of these laws. In the case of child migrants in Greece, these informal social forms of control include categorisations and associations that find expression in two phenomena: the discourse that is used to refer to migrants, which has shifted in Greece from one that is based on refugees to one that is based upon 'clandestine' migration, and the perceptions of Greek migrant children through the lenses of vulnerability and responsibility, which squeeze out 
opportunities to recognise their agency. The contingency of protection on these phenomena exemplifies both the plurality of the Greek migration legal system (see Gill and Good, introduction to this volume), and the challenges that this plurality presents to asylum seeking children.

The first part of the chapter sets out the history of human rights failings in the refugee context in Greece and the second section reflects upon the role of discourse surrounding refugees as a way of explaining why these failings persist. Drawing on two and a half years of participant ethnography in a Greek reception centre for children in Konitsa Town, Prefecture of Ioannina, Greece and in the Skaramagas Refugee camp in Attica Region, Athens, the third section then identifies three basic stereotypes that shape the perceptions of asylum seeking children among host communities in Greece. First, in contrast to the recommendations of contemporary scholarship about childhood (e.g. James et al. 1998) childhood is viewed as a linear, universal process implying that all children have the same needs. Second, separated children are seen as dependent burdens with no knowledge of their own 'best interests'. And third, like their adult counterparts, they are seen as 'undeserving migrants' that should be viewed with suspicion. Taken together, these findings demonstrate that the discourses and perceptions surrounding refugee children in Greece have had a decisive influence over their experiences of legal systems.

Chrisa took an anthropological and participatory approach to the fieldwork (Hardman 1973). When conducting her research with unaccompanied minors she tried to approach them as active participants in the construction and determination of their experiences, other people's lives and the societies in which they live (O'Kane 2008). In doing so she followed the advice of Christensen and James (2008: 3) who argue that we should not take the age-based adult/child distinction for granted' (ibid.: 3) and advocate 'that the particular methods chosen for a piece of research should be appropriate for the people involved in the study, for its social and cultural context and for the kinds of research questions that are being posed' (ibid.: 3). Accordingly, she always tried to address her participants as if they were adults, since they had managed to do something she had not-namely, they had irregularly crossed borders and walked many miles to get away from their country. For the purposes of the research she followed the methodology of semi-structured interviews, questionnaires and open discussions. In order to protect their anonymity, the research participants chose their own pseudonyms and at times we have created fictional composite characters (discussed below in more detail) to convey the experiences of interviewees without revealing their identities. 


\section{Greece's Record on Refugee Protection}

If the historical experience of refugees in Greece were a reliable indicator then we might expect Greece to be strongly committed to refugee protection. After the end of World War One and the signing of the Lausanne Treaty in January 1923, the Greek state received around one and a half million refugees from Asia Minor and Pontus as a result of the population exchange with Turkey at that time. ${ }^{1}$ The newcomers were resettled mostly in rural areas, in an attempt by Eleytherios Venizelos (the then-Prime Minister of Greece) to rebuild and fortify the rural territories, which had suffered severe damage due to the successive wars in which Greece participated from the beginning of the twentieth century.

As Voutira (2003: 66) argues, the term 'refugee', when referring to the 1923 refugees, is usually associated with positive connotations due to the collective perception of the 'successful' integration and publicly acknowledged contribution of Asia Minor refugees into twentieth-century Greek economic, social and cultural development, especially in these rural areas. Accordingly, throughout the post-1989 arrivals of Soviet Greeks from Pontus, the newcomers preferred the term 'refugee', rather than 'repatriee' or 'returnee'.

What is more, if the international community's assumptions about Greek refugee protection before 2007 were at all well-founded, then we might also expect Greece to be a model of refugee protection. For some time Greece was vaunted as a location in which the Geneva Convention, that sets the criteria for the recognition of refugee status and envisages universally applicable criteria for their protection, was reliably observed. According to the provisions of the Dublin II Regulation in $2003,{ }^{2}$ Greece was a place to which individuals could be safely returned if they had prematurely entered another European country during the examination period of their asylum applications. In other words, the international community has historically considered Greece an (extremely convenient) safe host country on the fringes of

\footnotetext{
${ }^{1}$ The full text of the Lausanne Treaty is available at: http://www.hri.org/docs/lausanne/ [Accessed 17 July 2017]. The full text of the Convention Concerning the Exchange of Greek and Turkish Populations is available at: http://www.hri.org/docs/straits/exchange.html [Accessed 17 July 2017].

${ }^{2}$ Council Regulation (EC) 343/2003 estabishing the criteria and mechanisms for determining the member state responsible for examining an asylum application lodged in one of the member states by a third-country national; see http://eur-lex.europa.eu/LexUriServ/LexUriServ.do?uri=OJ:L:2003:050:00 01:0010:EN:PDF [Accessed 17 July 2017].
} 
Europe as conveyed by its status as a first asylum country under article 1A of the Geneva Convention (Goodwin-Gill 1996).

In contrast to these assumptions about refugee rights in Greece, however, serious concerns about the provisions for refugees on the ground have been voiced for well over a decade. Skordas and Sitaropoulos (2004) for example argued that the deficiencies of the Greek refugee system included its archaism, the lack of efficient remedies and the inadequate social protection of refugees and asylum seekers. In October 2007, as a result of these and similar concerns, an extensive investigation into violations of the human rights of refugees at the various entry points into the country was carried out by the German non-governmental organisation 'PRO ASYL', with the participation of Greek organisations, and caused consternation due to the revelations that it produced (PRO ASYL 2007). The report cited evidence of the intentional refoulement of refugees at sea by the Greek coast guard by circling boats in order to cause waves that forced them to return, the deliberate damaging of refugee dinghies so that they could return to Turkey but not travel as far as Greece, the systematic abuse of newly arrived refugees, and the use of inhumane, degrading and illegal detention, as well as illegal deportation orders.

Following PRO ASYL's revelations various EU countries such as the UK, Germany, and Norway stopped referring asylum seekers to Greece (as the first country of entry according to the Dublin II procedure) while investigations into Greece's provision for refugees were carried out (see Craig and Zwaan, this volume, for a discussion of the principle of mutual trust between states subject to the Dublin regulations, as well as its modification under the Dublin III legislation). These investigations, and scrutiny from the international community more generally, prompted various attempted improvements to the Greek system of provisions. In November 2010, for example, Asylum Appeals Committees were introduced. ${ }^{3}$ These were three-member quasi-judicial bodies, consisting of a civil servant as Chairman, a member nominated by the United Nations High Commissioner for Refugees (UNHCR) and a member selected by the Ministry of Interior from a list drawn up by the National Commission on Human Rights (EEDA), an independent advisory body to the state. Their mandate was to examine the appeals on asylum applications submitted before the 6 June 2013 and rejected at the first instance by the Ministry

${ }^{3}$ Precedential Decree 114/2010 in conformity with Council Directive 2005/85/EC on minimum standards of procedures in Member States for granting and withdrawing refugee status. 
of Public Order (i.e. Greek Police officials). Furthermore, since November 2011 the Greek Police were no longer responsible for examining asylum applications. ${ }^{4}$ Rather, an autonomous service within the Ministry of Citizen Protection now held this responsibility. ${ }^{5}$

Nevertheless, although these legislative changes aimed for a fairer and more independent system, the practical autonomy of the new asylum system and the quality of the procedures should still be queried. For example, during 2016 the Asylum Appeals Committees that were created in 2010 were temporarily entrusted with examining appeals of asylum seekers who had entered the country from 20 March 2016 onwards-that is, the date from which the joint EU-Turkey statement was implemented. These were asylum requests deemed inadmissible at first instance examination based on recommendations of the European Asylum Support Office (EASO) representatives. In 390 out of 393 cases the Asylum Appeals Committees overruled the negative decisions of the first instance, after ruling Turkey a 'non-safe country'. Roughly two months later however, by virtue of an amendment approved by parliament on the 16 June 2016, the Asylum Appeals Committees ceased to be responsible for these cases, the examination of which was assigned to new committees with a different composition. This change in legislation has been widely criticised by human rights organisations. Refugee rights lawyers believe this was a cynical political intervention by the government in order to protect and promote a policy related to the implementation of the EU-Turkey statement, since the previous Asylum Appeals Committees did not comply with the political goal of sending Syrians back to Turkey. The National Committee for Human Rights and the Secretary General for Human Rights expressed concern and opposition to the Ministry's initiative at the time. In a public letter denouncing the amendment, 18 former Committee members, appointed by EEDA and UNHCR, warned that 'managing legal issues by use of political priorities raises many questions about the future of the asylum system in Greece, the protection of human rights and the rule of law' (see ECRE 2016; PRO ASYL 2016).

\footnotetext{
${ }^{4}$ Law 3907/2011 on the establishment of an Asylum Service and a First Reception Service (transposition into Greek legislation from Council Directive 2008/115/EC on common standards and procedures in Member States for returning illegally staying third country nationals and other provisions).

${ }^{5}$ For an overview of the Greek Asylum Legal Framework, main legislative acts and regulations relevant to asylum procedures, reception conditions and detention before and after the EU-Turkey Common Declaration on the 18 March 2016, see various reports from the Asylum Information Database, available at: http://www.asylumineurope.org/reports/country/Greece/overview-legal-framework [Accessed 20 July 2017].
} 


\section{From Refugees to Clandestines}

It is difficult to isolate a single root cause of the inadequate approach to refugee protection in Greece but economic factors must be seriously considered. The economic downturn that began in Greece in 2009 following the world financial crisis of 2007-2008, and culminated in Greece becoming the first developed country to miss an International Monetary Fund loan repayment in 2015 , has been accompanied by significant economic hardship across the country. This is evident in widespread job and income losses, as well as increasing levels of inequality. Through their analysis of the inequitable effects of austerity policies Matsaganis and Leventi demonstrate that 'almost one in ten people in 2012 were found to be not just in relative, but in extreme poverty in the sense of being unable to purchase the basic necessities consistent with dignified living' (2014: 220).

In turn, 'the economic crisis has brought a massive realignment of the Greek electorate away from mainstream parties, giving rise to anti-system and anti-immigrant sentiments' (Ellinas 2013: 543). Symptomatic of this realignment is the rise of Golden Dawn, a far-right nationalist Greek political party, whose vote share in national elections increased from $0.29 \%$ in 2009 to $6.97 \%$ in May 2012 and $9.39 \%$ in 2014, with its popularity among young voters almost double this (Ellinas 2013, 2015).

Contemporary refugees in Greece are often viewed in negative and hostile terms. They are seen to represent a burden on the host country, and a particular source of discontent arises when refugees are perceived to have a better life than some of the Greeks themselves. While it is to the credit of the Greek news media that they apparently do not associate refugees with terrorists to the extent that the British press do (Fotopoulos and Kaimaklioti 2016), the perception that refugees enjoy better treatment by the state than Greek homeless people is a key source of political and social tension. Indeed, the incidence of racist attacks rose during the height of the refugee crisis in 2015, with 273 incidents of racist violence recorded during that year (Racist Violence Recording Network 2015). This violence coincided with more attacks on human rights activists and 'alarming' (ibid.: 3) rates of involvement of law enforcement officials in incidents of racist violence.

The well-being of the asylum seekers and refugees in Greece is challenged further by the replacement of the term 'refugee' with the term 'lathrometanastis' (clandestine) in public discourse, mainly carried out by the media. This altered lexicon marks a distinction between the 1923 refugees who are strongly connected to the notion of national identity, and contemporary refugees. Although at the beginning of their settlement the 1923 refugees were 
in many cases treated as foreigners and described as Turk-originating, nowadays they are widely perceived as Greeks who survived a tragedy, and therefore of the same ethnicity as the host population. Contemporary refugees however, are viewed as foreigners, since their national identity is other than Greek.

The use of the term clandestine therefore deprives contemporary refugees of a semantic link to the positively-viewed refugees of the previous century. In Greek society, no distinction is made between foreigners and strangers: all of them are considered clandestine. The lack of distinction (according to the collective perception of Greek society) between migrants and refugees derives from the fact that they are all 'non-Greeks'. The reasons for their migration are not considered important enough to classify them as refugees. The 1922 refugees fought and fled from a national enemy, Turkey; although contemporary refugees have fled their enemies too, these enemies are not Greece's national enemies. Therefore, the identity label of 'refugee' seems to be reserved for migrants with a suitable national origin and a suitable enemy.

Such a blunt and essentialising distinction between Greeks and non-Greeks serves various purposes (see Young 1986). It references a mythological historical national purity, it 'denies difference' (ibid.: 1) by clumping together disparate identities, and it distances, or others, 'outsiders' in semantic and psychological terms. In turn, this distancing has physical effects. When entering Greece from the islands 'clandestines' are usually arrested and transferred to hotspots, with inferior living conditions (see Painter et al 2017; PallisterWilkins 2018; Taziolli and Garelli 2018). These are usually placed on the borders of Greece, far away from the capital and even further from the centre of Europe. The choice of these spaces is not random. It serves the policy of non-visibility: tactically employing distance and remoteness as ways to perform and inscribe the categorical differences that are being imposed (Mountz 2013; Gill 2016). In these ways the discourse surrounding 'clandestine' migration has spatial and legal manifestations. Migration law in Greece, then, must be viewed as co-produced: the product not only of formal rules and categories but also of social and linguistic norms. Discourses pluralise legal processes by constituting a set of informal norms that interact and compete with formal rules.

\section{The Perception of Unaccompanied Minors in the Humanitarian Context}

We now turn to the ways in which perceptions of children held by Greek officials have similar effects. Literature has highlighted how important it is to pay attention to whether refugee children are unaccompanied and/or 
separated from their parents in particular. Berman (2001) reviewed several studies that emerged on children and conflict following the Second World War and found that the importance of the family and community was a common theme throughout. It was shown that the separation of children from their parents was often more distressing than the bombs themselves (Berman 2001: 245). Garmezy (1983) also found that how children responded to living under the circumstances of war was greatly mediated by the significant adults in their lives.

The mid twentieth century witnessed an increased interest in protecting the rights of children and refugees. Several international conventions and agreements govern the treatment of asylum-seeking children. ${ }^{6}$ Most notable among these instruments are the 1951 UN Refugee Convention, the 1967 Protocol Relating to the Status of Refugees, and the 1989 UN Convention on the Rights of the Child (CRC). These instruments, however, follow one dominant cultural conception of childhood. They imagine children as having the same needs, regardless of their social, political, historical and economic context. While recognising that accompanied asylum seeking children face their own difficulties (Ottosson et al. 2017) it is usually unaccompanied asylum-seeking children who are thought of as most needy and whose 'remarkable coping capacities' (Hopkins and Hill 2010: 407) are often overlooked and even impeded by systems of support.

As expressed in some legal narratives, the notion of children as nonagential, passive and as simple recipients of care has been critiqued from various perspectives. Chase (2010) for example, argues that producing children as subjects with little or no agency can provoke an unfortunate backlash: children withhold vital information during the processing of their claim as an attempt to regain or reclaim agency over their lives. Crawley (2010) is also critical of the passive view of children that is entrenched in the legal discourse around refugees and unaccompanied asylum-seeking children, pointing to how a particular conceptualisation of childhood to be found in the legal approach, 'undermines the ability of children to fully articulate their experiences and to secure access to the protection to which they are entitled' (ibid.: 162). In other words, conceiving of children as passive and non-agential can be experienced by the children themselves as a lack of trust and respect.

\footnotetext{
${ }^{6}$ According to the UNHCR (1997: 1) unaccompanied minors are persons who are under the age of 18 and "who are separated from both parents and are not being cared for by an adult who, by law or custom, is responsible to do so".
} 
We now briefly set out the field sites in more detail, and then explore three ways in which perceptions of children held by officials impact upon young people's experiences of the legal processes that they go through.

\section{The Field Sites}

One of the field sites of the research was the reception centre in a small town in northwestern Greece. The space had been used since 1947, when Queen Frideriki established one of the so called Paidoupoleis-institutions that hosted children from the civil war stricken areas of Greece. In 1973 this Paidoupoli turned into an orphanage for Greek children. In the early 1990s it began hosting children from poor Albanian families as well. In 2008, following the need to create reception centres for separated asylum-seeking children, the Konitsa institution housed the first refugee children from Afghanistan and various African states. Chrisa visited this reception centre for the first time in 2009 and then spent a year visiting it on a daily basis while conducting field research for her Ph.D. thesis.

When she started visiting the reception centre, there were around 70 children residing there, belonging to three categories: orphan children from Greek families; children from Albanian families; and asylum-seeking children. Greek children were allowed to enroll in the Greek education system, or if they preferred they would attend the technical classes within the centre. The Albanian children were also allowed to attend the technical classes. The asylum-seeking children were not allowed to attend either a Greek school or the technical classes. The only provision for them was a daily two-hour class in Greek inside the centre. During discussions with them, they would often complain about life in the reception centre, how left aside and totally dependent on the decisions of the personnel they felt.

Another field site of the research is the Skaramagkas camp which started operating in April 2016, when a large number of asylum seekers who had been residing in the port of Piraeus in self-organised accommodation with tents were moved there by the Ministry of Migration. The space belongs to the Hellenic Navy and the site management is the responsibility of the Ministry of Migration. ${ }^{7}$ The Hellenic Navy used to provide the food via a

\footnotetext{
${ }^{7}$ From June 2017 till February 2018 the camp remained without site management, a fact that raised serious protection issues for all the population and in particular unaccompanied minors. As the official registration in the site was the responsibility of the site management, many people who came to Skaramagkas during that period could not get registered as residents in the camp, a fact that excluded
} 
catering contractor, and the Greek police are responsible for the safety of the camp. Beginning in June 2017, the NGO CARITAS (through UNHCR) provided cash cards with which the inhabitants could buy food. ${ }^{8}$ At the time of writing (mid 2017) there are almost 3000 people residing in the camp, all of them living in containers. The majority of the population is Syrian, followed by a minority of Iraqi Yezidis and Afghans. There are around 20 unaccompanied minors in the camp. Skaramagkas camp has a Safe Zone for unaccompanied minors and a Child Friendly Space (CFS) which functions under the supervision of a Child Protection actor. ${ }^{9}$ In her work as a legal advisor Chrisa has come across various cases that reflect unaccompanied minors' experiences of asylum procedures in Greece.

Since it was not possible to collect consent to use the interviewees' direct testimony during Chrisa's work as a legal advisor we employ a variety of measures. First, we do not quote from these interviewees at all. Second, we follow the methodology of composing fictions as a means of protecting the identity of the people Chrisa spoke to from this site (Gough 2008: 338-340). That is, we present fictional accounts concerning fictional characters. These accounts are analogous to the accounts that Chrisa heard but do not correspond to single, real individuals. They are intended to be realistic, but not real. They are broadly based on the experience of a number of individuals, but are fictionalised in terms of content, sequence as well as the correspondence between events and the narratives that we ascribe to the characters we discuss. In this way we are able to convey the frustrations of the people Chrisa spoke to without compromising their privacy. While 'in much everyday speech fiction is equated with falsehood' (ibid.: 339) this approach recognizes the narrative force of fiction as a means of conveying certain forms of truth. If the assumption is made that academic research is chiefly concerned with documenting facts without distorting them, then it is reasonable to suppose that there is no place for fiction in academic work. But academic work, especially ethnographic work that seeks to convey

them from the cash card program. Unaccompanied minors arriving at that time became invisible to the national response system as the actor responsible for registering them with EKKA (The National Centre for Social Solidarity, which is the institution responsible for placing them into shelters) was absent.

${ }^{8}$ In the months that followed the cash cards were provided directly by UNHCR.

${ }^{9}$ Safe Zones and CFS can be found in many camps both in the mainland and the islands of Greece. However, the Safe Zones have limited places and often cannot accommodate all the unaccompanied minors of the camp. 
meaning and feelings, is concerned with more than the brute transmission of facts. As such, 'storying' (Piper and Sikes 2010: 568) can be an indispensable strategy towards the fulfilment of academic objectives and 'an important strategy for protecting vulnerable participants' (ibid.: 573). In what follows then, the characters Ali, Jamal, Jafar and Fatima are fictional.

In terms of languages used, in the case of Konitsa Reception Centre Chrisa used the Arabic and Farsi interpreters who worked in the centre. She spoke directly with African minors in English. In the case of Skaramagkas she used the Farsi, Sorani and Arabic interpreters working for an NGO operating in the site.

\section{Childhood as Linear and Universal}

The first perception of children that becomes evident in the two sites is the view of childhood as a linear and universal process that is highly dependent upon chronological age. This view has been lambasted by the new social studies of childhood, which emphasise that 'the child [should be] conceived of as a person [and...] a social actor [...] in its own right. It does not have to be approached from an assumed shortfall of competence, reason or significance' (James et al. 1998: 207). Anthropologists in particular have played a decisive role in critiquing the 'universalist account of childhood' (LeVine 2007: 250) that emerged in the last century from childhood cognitive development theory and developmental psychology.

One of the most revealing narratives in the case of the Konitsa reception centre came from the personnel themselves. According to one of them:

They are kids, they don't know what is best for them. We treat them as our own kids. I wouldn't, for example, allow my child to visit friends that I don't know, or have a sleepover at someone else's house at that age. That is why we don't allow them to visit their friends in Ioannina [a nearby town]. They are under our responsibility.

In this view of childhood there is often the underlying assumption that children (taken to be people under 18 years of age) require protection, that they may not be capable of defining their 'best interests', and that they are less able to cope with violence and forced migration than their adult counterparts.

This view of childhood often backfires though, as "Ali's" case illustrates. Ali is a 16-year-old unaccompanied minor from Iraq who arrived in Greece with three of his older, adult male relatives in early 2015 . Ali spent much of 
his early teenage years fighting for survival alongside his older relatives, and is a capable and agential individual. When they arrived in Chios Island, for example, they stayed on the streets for some days and then boarded a ship to Piraeus Port before travelling independently to Thessaloniki. There they followed a group of people who were heading towards Eidomeni (a village by the Greek-Macedonian Border). ${ }^{10}$ They stayed there for a number of months but got separated when the border closed.

Ali's older relatives made it to Sweden but Ali was first detained for a few days and then sent to a shelter for unaccompanied minors in Thessaloniki after Eidomeni was evacuated. In this way measures that were framed as 'protective' became a source of aggravation for Ali, reminiscent of Fassin's (2005: 362) 'compassionate repression'. Because he was under 18 years old he was entered into a slower and more cumbersome administrative process, setting in motion a tension between his agential capabilities and the passive and immobile child that he was expected to be. He left the shelter there after a few days and returned to Piraeus Port where around 1500 migrants and refugees had set up an informal settlement in two of the port's docks. In Spring 2016 he was sent to Skaramagkas camp along with the majority of the people who had found shelter in Piraeus Port.

Later that year Ali was arrested and detained in Igoumenitsa Port, western Greece, while he was trying to board a ship to Italy. On his release Ali told the lawyer that he would not register again with a shelter and that he wanted to return to Skaramagkas camp. In other words he was once again refusing the 'help' that was provided for children. He also refused any referral to Child Protection officials who provide psychosocial support.

Eventually he reached France and has plans to leave for Sweden to join his older relatives. Throughout his time in Greece he insisted that he did not want to live in a shelter because he felt that he was treated as a child rather than as an adult. He did not want to be referred to Child Protection officials because they would not understand that he was capable of living on his own. Ali had lost his patience and did not trust the asylum procedures in Greece due to the huge delays in registering with the asylum service and the family reunification process. He never revealed his plans about leaving Greece irregularly to any of the adults involved in his 'protection', out of fear that they would call the public prosecutor to force him into a shelter. For

\footnotetext{
${ }^{10}$ Eidomeni is the place where, in the summer of 2015, refugees and migrants gathered to cross the border to Macedonia and continue their journey towards the North of Europe. Many made it through until February 2016, when Macedonia closed the borders. For detailed information concerning the situation at the Greek-Macedonian borders at the time see Amnesty International (2015).
} 
him, all Child Protection officials did nothing to help his case and did not understand his anguish at being left behind by his older relatives. All he saw was a complicated bureaucratic system that was unsympathetic towards him, and adults who do nothing to help. In other words, Ali felt that he had to actively resist the model of childhood that was being imposed upon him by officials, who could not see past his numeric age. From his perspective their interventions were simply slowing his progress towards reunification with his family. Attempts to 'help' backfired in the sense that they not only caused additional frustration but also contributed to Ali's separation from his family and led him to take further risks in pursuit of reunification with them.

Ali's experience was not unusual. "Jamal", another 16-year-old from Iraq in the Skaramagkas camp, tried to leave Greece in the summer of 2016 and was arrested by the Greek Police. He had been trying for two months. He had arrived with his uncle but the Asylum Service did not allow his uncle to be registered as Jamal's legal guardian because of the lack of documentation proving that Jamal was really his uncle's nephew. As a result his uncle's immediate family were relocated to France, but Jamal could not follow.

\section{Separated Children as Dependent Burdens}

A second perception about asylum seeking children is that they are dependent, and therefore burdensome to either their guardians or to the state. According to Zetter (1999: 74) this dependency discourse is a powerful tool used to restrict and contain refugees. Refugees tend to be viewed as:

a burden of dependency on the community. The concept of sanctuary coupled with the loss of familiar economic and social support systems and individual autonomy combine to construct a powerful image of dependency and the need for assistance.

The dependency discourse goes hand-in-hand with a humanitarian discourse. Malkki (1996) argues that the 'burdensome' representation of refugees-manifested in the work of refugee agencies, government and non-government organisations as well as media-has serious consequences for their lives. While she recognises that these representations help to raise funds and resources, they also silence their subjects.

$[R]$ efugees suffer from a peculiar kind of speechlessness in the face of the national and international organisations under whose object of care and 
control they are. Their accounts are disqualified almost a priori, while the languages of refugee relief, policy science, and 'development' claim the production of authoritative narratives about refugees. (Malkki 1996: 386)

In the case of the refugee children Chrisa spoke to in Konista, the perception of children as dependent was at odds with their evident ability and desire to work, but at times was a self-fulfilling perception because it prohibited this very activity. Farzin from Iran, for example, explained that it was precisely the lack of opportunity to work that kept him trapped in the reception centre for children. 'I have walked for over a month to reach Greece. I can take care of myself', he explained,

If I had had some money I would have left this place a long time ago. It is so boring and it offers us nothing. I am not afraid to go to Germany alone. Some friends of mine made it, why not me? With the proper amount of money, a smuggler can take you anywhere. That is why I have to find a job immediately.

Mohamad from Senegal concurred. 'We have requested that they allow us to work in the fields here in Konitsa, but they don't permit it,' he complained. 'But we need the money so we can get around by ourselves. Plus, what should we do all day? There is nothing here for us. We only sleep, eat and play football. They either treat us like very small children or they ignore us altogether.

The dependence discourse also acts to deny under $18 \mathrm{~s}$ the opportunity to take part in supposedly 'adult' activities, which often reflects a western, conservative view of childhood. One under-18 Afghan refugee who spent time at the Konitsa reception centre explained that, 'They don't even allow us to help in the kitchen or suggest what we want to eat. We never chose our clothes, we get whatever people give us'. Another refugee, "Jafar", a 17-yearold from Afghanistan, travelled to Greece with his sister. She managed to reach the Netherlands and apply for asylum there but he was unable to follow. He wanted to stay in the Skaramagas camp, even though he conceded that it is more dangerous than a shelter for children like the one at Konitsa. Despite the fact that he has had his money and mobile phone stolen in the camp, and that he really hates the food there, he values the fact that he can smoke and go out at night, while in Konitsa he is treated like a little child. Jafar tried to leave Greece twice on his own and succeeded the second time.

One of the most concerning consequences of the dependency discourse is its ability to undermine the trust of refugees in systems of protection, which has been recognised as an 'essential component' (Hynes 2009: 97) of their 
effectiveness. "Fatima", a 14-year-old from Syria, arrived in Greece in 2016 with her adult brother and his family. They all applied for relocation but like Jamal, her brother could not be considered her legal guardian due to the lack of relevant documentation. Her brother, who lived in the Skaramagkas camp, was accepted by Germany via the relocation procedure. Thinking that Fatima faced the prospect of living in a shelter for unaccompanied minors in Greece, she and her brother made the decision for her to attempt to go back to Turkey on her own - a dangerous and illegal route- to try to reconnect with other members of her family there.

Fatima's attempt to return to Turkey was unsuccessful: she was caught and arrested in the Evros region. She was detained for almost ten days before she was sent to a shelter for children in Athens. Her experience raises the questions of who she was fleeing from, and who she was trapped by.

\section{Separated Children as Undeserving}

Another aspect of the rhetoric concerning asylum seeker children is that of the undeserving migrant who manipulates the social care system of the hosting country. ${ }^{11}$ According to Watters (2008: 47): “Asylum seekers" [has become] a term in everyday discussion inextricably linked to imagery of cunning and manipulative foreigners securing generous material rewards from a hopelessly gullible government'. This perception was strongly in evidence among the staff at Konitsa. 'They are not really refugees' one of them told Chrisa,

They falsify their personal data to present themselves as refugees and take advantage of the protection our state gives them. Some of them are not even children. They are clandestine. I wonder, how could their parents ever let them travel so far away from home? Why don't they work, instead of sending their children to a foreign country to make money? I would never ask that of my son.

In her ethnography of a British detention centre, Alexandra Hall (2012) identifies the tendency among staff to assume that illegality is a matter of

\footnotetext{
${ }^{11}$ This is currently the case with unaccompanied minors from Pakistan, Bangladesh and African countries. Due to the perception of the Asylum Service that the citizens from these countries fall under the category of the migrant rather than the refugee, their asylum claims are usually rejected. The minors are thus put in a "limbo" situation with regards to their residence status, since they cannot be deported as long as they are minor, nor enjoy a rights holders' position.
} 
individual choice. In turn, this illegality, for the staff, is 'because of their morally compromised and weak character rather than desperation and necessity' (ibid.: 102). This produces a perception of undeservingness, according to which certain supposedly nefarious individuals choose to take from, but not to contribute towards, their host society. In this discourse, migrants are viewed as attempting to 'escape work or fraudulently claim benefits, or to work illegally and escape paying taxes' (ibid.: 103). The telltale signs of such inauthenticity, as far as the staff at Hall's detention centre were concerned, included everything from complaining about conditions and displaying too much emotion to food refusal.

Under conditions of such skepticism, moral condemnation on the basis of undeservingness is common, and is keenly felt by the residents of Konitsa. 'The personnel do not like us' Mohamed from Senegal surmised. 'They never have time for us, they don't even have an interpreter in French. There is only one television with Greek channels. We have asked them many times to arrange it so we can watch some French channels as well, but nothing'. Rizula from Afghanistan agrees, explaining that:

The personnel don't treat us well. They are much more giving towards the Albanians and the Greeks. They don't allow us to go to the Greek school and they don't allow us to attend the classes inside the centre either. When we tell them that we are bored here in Konitsa they never listen. There is nothing here but a small town and mountains.

These frustrations are exacerbated by not only insensitive media reporting, but also a feeling among the residents that the staff assent to such insensitivity. 'When we started visiting the local football pitch, the local newspaper wrote an article claiming that we suffer from infectious diseases,' Rizula told Chrisa. What made the situation worse was the distinct lack of support that the refugee children received from the staff at Konitsa. 'The personnel never supported us.' Rizula recalled, displaying her own moral indignation at their inactivity.

\section{Conclusion}

This chapter has demonstrated how 'nonlegal forms of normative ordering' (Merry 1988: 870) such as those that inhere in national discourses and perceptions, and that are held by legal subjects themselves, can interrupt and recast formal legal structures. While international law sets out 
a series of ways in which refugee protection is supposed to operate, the Greek case illustrates the importance of plural influences, beyond formal law itself, in the determination of legal experiences and outcomes. These include the influences of language, cultural history, economic conditions and assumptions about childhood. In other words, the case of refugee law is one example of how 'other forms of regulation outside law constitute law' (ibid.: 874).

In various ways, these influences do not auger well for refugee rights in Greece. The association of refugees with the discourse of clandestine migration has coincided with a marked increase in poverty, inequality and anti-immigration sentiment in the country. Although the lack of resources and its position as a first safe country of asylum under the Dublin regulations should not be overlooked in explaining the lacklustre approach to refugee rights in Greece (see Fili and Xythali 2017), the close 'relations between the legal discourse and other social discourses' (Teubner 1991: 1446) that scholars of legal pluralism identify is also a factor. The clandestine discourse has the effect of homogenising and othering the refugee population, which paves the way for the sort of exclusionary and illegal practices that PRO ASYL and Human Rights Watch have condemned in the country.

Nevertheless, as scholars of legal pluralism have argued, these interruptions can also 'sometimes be desirable' (Berman 2006: 1155) when they result in 'alternative ideas' (ibid.: 1155). The majority of the minors that participated in the research faced great difficulties in understanding the reasoning behind the asylum procedures in Greece and Europe and posed very particular questions: "why can't I go where I want", "why can't I chose how to live" and "why don't states ask me what I want"? To be sure, these difficulties often result in negative outcomes: distrust of authorities for example, risk-taking and reliance on dangerous social networks. By questioning these things and signaling their discontent, however, asylum seeking children are also insisting on a different conceptualisation of childhood. For example, most of them refused to identify themselves as just 'vulnerable' as they felt it deprived them of the right to claim their maturity. They would accept their legal classification as vulnerable only if it would speed up the legal procedures that concerned them. These sorts of extra-legal interruptions of the logic of international refugee law could be productive if they cause legal practitioners to reevaluate the categories, assumptions and values that this body of law associates with being under 18 years of age. 


\section{References}

Amnesty International. (2015). Europe's Borderlands: Violations Against Refugees and Migrants in Macedonia, Serbia and Hungary. Available at: https://www.amnestyusa.org/files/ser-mac_migration_report_final.compressed.pdf. Accessed 17 July 2017.

Berman, H. (2001). Children and War: Current Understandings and Future Directions. Public Health Nursing, 18(4), 243-252.

Berman, P. (2006). Global Legal Pluralism. Southern California Law Review, 18(24), $1-55$.

Black, R. (1994). Livelihoods Under Stress: A Case Study of Refugee Vulnerability in Greece. Journal of Refugee Studies, 7(4), 360-377.

Chase, E. (2010). Agency and Silence: Young People Seeking Asylum Alone in the UK. British Journal of Social Work, 40(7), 2050-2068.

Christensen, P., \& James, A. (Eds.). (2008). Research with Children: Perspectives and Practices (2nd Ed.). London and New York: Routledge.

Crawley, H. (2010). 'No One Gives You a Chance to Say What You Are Thinking': Finding Space for Children's Agency in the UK Asylum System. Area, 42(2), 162-169.

European Council for Refugees and Exiles (ECRE). (2016). Greece Amends Its Asylum Law After Multiple Appeals Board Decisions Overturn the Presumption of Turkey as a Safe Third Country. Available at: http://www.ecre.org/greece-amendsits-asylum-law-after-multiple-appeals-board-decisions-overturn-the-presumption-of-turkey-as-a-safe-third-country/. Accessed 20 July 2017.

Ellinas, A. (2013). The Rise of Golden Dawn: The New Face of the Far Right in Greece. South European Society and Politics, 18(4), 543-565.

Ellinas, A. (2015). Neo-Nazism in an Established Democracy: The Persistence of Golden Dawn in Greece. South European Society and Politics, 20(1), 1-20.

Fassin, D. (2005). Compassion and Repression: The Moral Economy of Immigration Policies in France. Cultural Anthropology, 20(3), 362-387.

Fili, A., \& Xythali, V. (2017). Unaccompanied Minors in Greece: Who Can 'Save' Them? Border Criminologies. Available at: https://www.law.ox.ac.uk/research-subject-groups/centre-criminology/centreborder-criminologies/blog/2017/02/unaccompanied. Accessed 20 July 2017.

Fotopoulos, S., \& Kaimaklioti, M. (2016). Media Discourse on the Refugee Crisis: On What Have the Greek, German and British Press Focused? European View, 15(2), 265-279.

Garmezy, N. (Ed.). (1983). Stressors of Childhood. Minneapolis: McGraw-Hill.

Gibb, R., \& Good, A. (2014). Interpretation, Translation and Intercultural Communication in Refugee Status Determination Procedures in the UK and France. Language and Intercultural Communication, 13(3), 385-399. 
Gill, N. (2016). Nothing Personal? Geographies of Governing and Activism in the British Asylum System. Oxford: Wiley-Blackwell.

Goodwin-Gill, G. (1996). The Refugee in International Law. Oxford: Oxford University Press.

Gough, N. (2008). Fictional Writing. In L. Given (Ed.), The Sage Encyclopedia of Qualitative Research. Los Angeles, London, New Delhi and Singapore: Sage.

Hall, A. (2012). Border Watch: Cultures of Immigration, Detention and Control. London: Pluto Press.

Hardman, C. (1973). Can There Be an Anthropology of Children? Journal of the Anthropological Society of Oxford, 4(2), 85-99.

Hopkins, P., \& Hill, M. (2010). The Needs and Strengths of Unaccompanied Asylum-Seeking Children and Young People in Scotland. Child and Family Social Work, 15(4), 399-408.

Human Rights Watch. (2016). "Why Are You Keeping Me Here” Unaccompanied Children Detained in Greece. New York: Human Rights Watch. Available at: https://www.hrw.org/sites/default/files/report_pdf/greece0916_web.pdf. Accessed 17 July 2017.

Hynes, P. (2009). Contemporary Compulsory Dispersal and the Absence of Space for the Restoration of Trust. Journal of Refugee Studies, 22(1), 97-121.

James, A., Jenks, C., \& Prout, A. (1998). Theorizing Childhood. Williston, VT: Teachers College Press.

Keselman, O., Cederborg, A., Lamb, M., \& Dahlström, Ö. (2008). Mediated Communication with Minors in Asylum-Seeking Hearings. Journal of Refugee Studies, 21(1), 103-116.

LeVine, R. (2007). Ethnographic Studies of Childhood: A Historical Overview. American Anthropologist, 109(2), 247-260.

Malkki, L. (1996). Speechless Emissaries: Refugees, Humanitarianism, and Dehistoricization. Cultural Anthropology, 11(3), 377-404.

Matsaganis, M., \& Leventi, C. (2014). Poverty and Inequality During the Great Recession in Greece. Political Studies Review, 12(2), 209-223.

Merry, S. (1988). Legal Pluralism. Law and Society Review, 22(5), 869-896.

Mountz, A. (2013). Mapping Remote Detention: Dis/Location Through Isolation. In J. Loyd, M. Mitchelson, \& A. Burridge (Eds.), Beyond Walls and Cages: Prisons, Borders, and Global Crisis. Athens and London: The University of Georgia Press.

O'Kane, C. (2008). The Development of Participatory Techniques: Facilitating Children's Views About Decisions Which Affect Them. In P. Christensen \& A. James (Eds.), Research with Children: Perspectives and Practices (2nd ed.). London and New York: Routledge.

Ottosson, L., Eastmond, M., \& Cederborg, A. (2017). Assertions and Aspirations: Agency Among Accompanied Asylum-Seeking Children in Sweden. Children's Geographies, 15(4), 426-438.

Painter, J., Papada, E., Papoutsi, A., \& Vradis, A. (2017). Hotspot Politics-Or, When the EU State Gets Real. Political Geography, 60, 259-260. 
Pallister-Wilkins, P. (2018). Hotspots and the Geographies of Humanitarianism. Environment and Planning D: Society and Space. Online First.

Piper, H., \& Sikes, P. (2010). All Teachers Are Vulnerable but Especially Gay Teachers: Using Composite Fictions to Protect Research Participants in PupilTeacher Sex-Related Research. Qualitative Inquiry, 16(7), 566-574.

PRO ASYL. (2007). The Truth May Be Bitter But It Must Be Told: The Situation of Refugees in the Aegean and the Practices of the Greek Coast Quard. Available at: https://www.proasyl.de/wp-content/uploads/2007/10/Griechenlandbericht_ Engl.pdf. Accessed 19 July 2017.

PRO ASYL. (2016). Greek Government in Court for Introducing Unconstitutional Second Instance Asylum Committees. Available at: https://www.proasyl.de/ en/news/greek-government-in-court-for-overruling-independent-second-instance-asylum-committees/. Accessed 20 July 2017.

Racist Violence Recording Network. (2015). Annual Report. Available at: http:// rvrn.org/wp-content/uploads/2016/04/Report_2015eng.pdf. Accessed 20 July 2017.

Rycroft, R. (2005). Communicative Barriers in the Asylum Account. In P. Shah (Ed.), The Challenge of Asylum to Legal Systems. London: Cavendish.

Skordas, A., \& Sitaropoulos, N. (2004). Why Greece Is Not a Safe Host Country for Refugees. International Journal for Refugee Law, 16(1), 25-52.

Teubner, G. (1991). The Two Faces of Janus: Rethinking Legal Pluralism. Cardozo Law Review, 13, 1443-1462.

Tazzioli, M., \& Garelli, G. (2018). Containment Beyond Detention: The Hotspot System and Disrupted Migration Movements Across Europe. Environment and Planning D: Society and Space. Early view.

United Nations High Commissioner for Refugees. (1997). Guidelines on Policies and Procedures in Dealing with Unaccompanied Children Seeking Asylum. Available at: http://www.unhcr.org/3d4f91cf4.pdf. Accessed 2 Aug 2017.

Voutira, E. (2003). Refugees: Whose Term Is It Anyway? Emic and Etic Constructions of 'Refugees' in Modern Greek. In J. van Selm, K. Kamanga, J. Morrison, A. Nadig, S. Špoljar- Vržina, \& L. van Willigen (Eds.), The Refugee Convention at Fifty: A View from Forced Migration Studies. Lanham, MD: Lexington Books.

Watters, C. (2008). Refugee Children: Towards the Next Horizon. New York: Routledge. Woodman, G. (1998). Ideological Combat and Social Observation: Recent Debate About Legal Pluralism. The Journal of Legal Pluralism and Unofficial Law, 30(42), 21-59.

Young, I. (1986). The Ideal of Community and the Politics of Difference. Social Theory and Practice, 12(1), 1-26.

Zetter, R. (1999). International Perspectives on Refugee Assistance. In A. Ager (Ed.), Refugees: Perspectives on the Experiences of Forced Migration. New York: Cassell. 
Open Access This chapter is distributed under the terms of the Creative Commons Attribution 4.0 International License (http://creativecommons.org/licenses/ by/4.0/), which permits use, duplication, adaptation, distribution and reproduction in any medium or format, as long as you give appropriate credit to the original author(s) and the source, a link is provided to the Creative Commons license and any changes made are indicated.

The images or other third party material in this chapter are included in the work's Creative Commons license, unless indicated otherwise in the credit line; if such material is not included in the work's Creative Commons license and the respective action is not permitted by statutory regulation, users will need to obtain permission from the license holder to duplicate, adapt or reproduce the material.

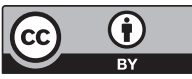

